\title{
Ukraine deluged by protests over plans for Danube delta
}

\section{Quirin Schiermeier, Munich}

Ukraine is coming under growing international pressure to halt the construction of a shipping canal through the ecologically sensitive Danube delta. Critics say the project will damage some important fish and wetland bird habitats, and increase erosion on the Black Sea coast.

Yet despite a mass of protests from scientists, environmentalists and national governments, work continues on the site. Protesters say the only concession made by Ukraine so far is a promise last week to open lines of communication to concerned parties.

The Danube delta is no stranger to environmental havoc. In the 1980s, Nicolae Ceausescu, Romania's communist dictator, disastrously tried to transform large parts of the wetland into arable land. Since his execution in 1989 the area has recovered — but environmentalists say it is again under threat.

The Ukrainian government is in the middle of a $€ 30$-million (US\$37-million) plan to expand a natural waterway called the Bystroye Canal, which connects the outflow of the River Danube to the Black Sea. This waterway was once used for shipping, but its ports closed after the 1994 Balkan war. Since then the waterway has filled with silt, causing the economy of the region also to stagnate.

By August, a 3kilometre stretch of the waterway had been dug, making it passable for large cargo ships once more.

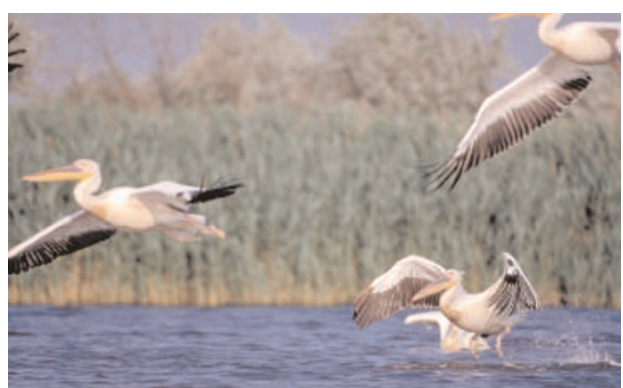

Delta blues: a canal expansion may oust white pelicans.

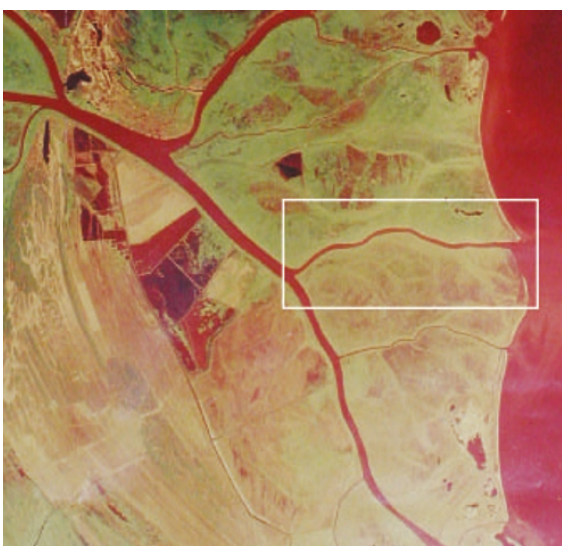

The right course? A 3-km stretch (boxed) of waterway to the Black Sea has already been dug.

concerned about Ukraine's repeated deafness to the recommendations of the international community," he says.

Although critics acknowledge that the impoverished region needs a new port, they say there are better places to carve a canal.

In the past few months, the United States and the European Union have officially asked Ukraine to stop all construction work pending an independent scientific assessment.

Following a visit from the European Commission and Ramsar convention delegates last week, Ukraine has promised to increase communication with those concerned about the project. Deputy transport minister Valentin Kasapchuk Work is expected to continue on 170 kilometres of the channel until 2007; it will then have to be continually dredged to stay navigable.

Ukrainian authorities say the project carries no serious environmental risks. But ecologists fear that continuing the work will destroy bird and fish habitats. The delta is currently home to some 300 bird species, including many rare birds such as white pelicans and pygmy cormorants. The labyrinth of waterways, lakes and dunes was declared a World Heritage site by the United Nations in 1991, and was made a Wetland of International Importance under the Ramsar Convention on Wetlands in 1995.

"We want to clearly state that the convention does not endorse the Bystroye project in its current design," says David Bridgewater, secretary-general of the Ramsar convention, based in Gland, Switzerland. "We are deeply says the country will convene an international meeting of experts in November to examine the likely impact of the project's next phase. He promises that there will be further monitoring of the environmental impact before construction continues.

Scientists and environmental groups hope to bring to officials' attention more than concerns about biodiversity. Geologists, for example, warn that the expansion will dramatically increase discharge from the Danube through the channel, depriving other parts of the delta of water, and causing coastal erosion.

Liviu Giosan, a marine geologist at Woods Hole Oceanographic Institution in Massachusetts, plans to use computer models to simulate the potential changes in the delta so as to better assess the impact of the project. "It's about time we stopped gambling with the future of a natural paradise," says Giosan.
Canada to join 'big league' with its own science academy

David Spurgeon, Montreal

Rectifying an omission that has irked its scientists for decades, the Canadian government is to mandate the creation of a Canadian Academies of Science.

The mandate, announced on 5 October by Prime Minister Paul Martin, will create what one adviser calls "an exact analogue" of the US National Academies, albeit on a smaller scale.

The academy will operate at arm's length from government, Martin said, although it will receive Can $\$ 35$ million (US\$28 million) of government funding over the next ten years. The arrangement will provide "a source of expert advice on scientific aspects of important domestic and international issues", he added.

For years, the Royal Society of Canada has performed one-off studies of issues for government departments, through ad hoc panels operating under the rubric of the Canadian Academy of the Sciences and Humanities. But in contrast to the situation in the United States, the society operated without either a professional staff or a formal government mandate.

In 2002, the government's industry department announced plans to create a proper Canadian science academy (see Nature 415, 824; 2002), but until this year nothing had been done to implement them.

William Leiss, a political scientist at Queen's University in Kingston, Ontario, and a past president of the Royal Society, has been advising the government on the proposed academy. He says Martin's announcement "will allow us to play with the boys in the big leagues".

Leiss was also involved in setting up the previous one-off studies. These included a controversial 2001 investigation of genetically modified foods (see Nature 409, 749; 2001). But he says such studies were "very tricky" to undertake, because their reliance on government grants made it hard for them to appear truly independent.

For many scientists and policy specialists in Canada, the foundation of a proper academy structure is decades overdue. "It should have been done a long time ago," says Leiss. “The US National Academies have original legislation going back to 1863 and the Royal Society in Britain has had a relationship with the British government since 1849." Even smaller countries such as the Netherlands and Austria have established similar bodies, he says. "It's been terribly frustrating for us." 